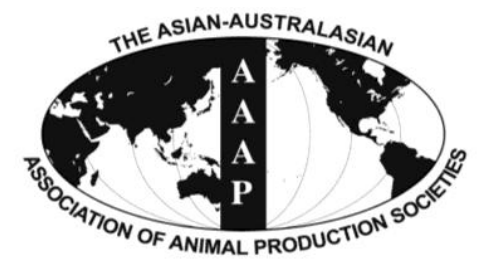

Asian-Aust. J. Anim. Sci.

Vol. 25, No. 5 : 642 - 647

May 2012

www.ajas.info

http://dx.doi.org/10.5713/ajas.2011.11256

\title{
Effects of Two Halophytic Plants (Kochia and Atriplex) on Digestibility, Fermentation and Protein Synthesis by Ruminal Microbes Maintained in Continuous Culture
}

\author{
A. Riasi ${ }^{1,2, *}$, M. Danesh Mesgaran, M. D. Stern ${ }^{3}$ and M. J. Ruiz Moreno ${ }^{3}$ \\ Department of Animal Science, Faculty of Agriculture, Ferdowsi University of Mashhad, \\ P.O. Box 91775-1163, Mashhad, Iran
}

\begin{abstract}
Eight continuous culture fermenters were used in a completely randomized design to evaluate various nutritional values of Kochia (Kochia scoparia) compared with Atriplex (Atriplex dimorphostegia). Dried and pelleted samples (leaves and stems) provided substrate for metabolism by ruminal microbes maintained in a continuous culture fermentation system. Results indicated that there were no differences $(\mathrm{p}>0.05)$ in dry matter $(\mathrm{DM})$ and crude protein $(\mathrm{CP})$ digestibility between the two halophytic plants. Atriplex had higher $(\mathrm{p}<0.05)$ organic matter $(\mathrm{OM})$ digestibility compared with Kochia. Neutral detergent fiber (aNDF) digestibility of Atriplex (411 g/kg) was higher $(\mathrm{p}<0.05)$ than that of Kochia $(348 \mathrm{~g} / \mathrm{kg})$, however acid detergent fiber (ADF) digestibility was higher $(\mathrm{p}<0.05)$ in Kochia compared with Atriplex (406 vs. $234 \mathrm{~g} / \mathrm{kg}$ ). There were no differences ( $>0.05$ ) between the two halophytic plants in molar proportion of acetate and propionate, but the concentration of butyrate and valerate in Kochia were about two fold of Atriplex ( $\mathrm{p}<0.05)$. When Kochia provided substrate to the microbes, protein synthesis was higher ( $\mathrm{p}<0.05)$ compared with feeding Atriplex (5.96 vs. $4.85 \mathrm{~g} \mathrm{~N} / \mathrm{kg}$ of OM truly digested). It was concluded that Kochia scoparia and Atriplex dimorphostegia had similar digestibility of DM and CP. It appears that these halophytic plants may not have enough digestible energy for high producing ruminants. (Key Words: Halophytic Plants, Continuous Culture, Digestibility, Microbial Protein)
\end{abstract}

\section{INTRODUCTION}

Halophytic plants constitute a significant part of the local flora in arid and semiarid regions and in many cases represent supplementary or emergency feed during the prolonged seasons of drought. These forages are grazed by sheep, goats and camels and usually contain sufficient crude protein and (or) carbohydrate components to have significant nutritional potential. During the last two decades, there has been increased interest in planting halophytes in salty agricultural regions around the world (Riasi and

\footnotetext{
* Corresponding Author: A. Riasi. Tel: +98-311-391-3370, Fax: +98-311-391-3371, E-mail: ariasi@cc.iut.ac.ir

${ }^{1}$ Department of Animal Science, College of Agriculture, Ferdowsi University of Mashhad, Mashhad, Iran.

2 Present address: Department of Animal Science, College of Agriculture, Isfahan University of Technology, Isfahan, Iran.

${ }^{3}$ Department of Animal Science, College of Food, Agricultural and Natural Resource Sciences, University of Minnesota, St. Paul, MN 55108, USA.

Submitted Jul. 31, 2011; Accepted Nov. 2, 2011; Revised Nov. 10, 2011
}

Danesh Mesgaran, 2008). Kochia spp. and Atriplex spp. that belonging to the chenopodiaceae family, have considerable forage potential in the arid and semiarid rangelands of West Asia. General nutritional characteristics of these plants have been well defined (Gihad and El Shaer, 1992; El-Shatnawi and Turuk, 2002; Danesh Mesgaran and Stern, 2005; Riasi et al., 2008). However, more information on how these plants affect microbial fermentation in the rumen needs to be determined for them to be effectively used as a forage source for ruminant animals.

Dual flow continuous culture fermenters that simulate the ruminal environment have been used to measure feed digestion and microbial metabolism (Stern et al., 1997). In addition, continuous culture systems provide a means to evaluate the effect of nutrients on metabolism of microbes maintained under controlled $\mathrm{pH}$, turnover rate and nutrient intake (Michalet-Doreau and Ould-Bah, 1992). Currently, there is only limited data for digestibility and ruminal fermentation parameters of halophytic plants using the in vitro methods. The objective of this experiment was to study the nutritive value of Kochia scoparia and Atriplex 
dimorphostegia using the continuous culture fermenter system.

\section{MATERIAL AND METHODS}

\section{Halophytic plants and continuous culture study}

Samples of Kochia scoparia and Atriplex dimorphostegia (stems and leaves) were harvested at mid bloom stage from the Salinity Research Station of Birjand University with clay-sandy soil $(\mathrm{pH}=7.4$ and $\mathrm{EC}=10.3$ $\mathrm{dS} / \mathrm{m})$ and salty irrigation water $(\mathrm{pH}=6.8, \mathrm{EC}=5.5 \mathrm{dS} / \mathrm{m}$, and $\left.\mathrm{Na}^{+}=24.7 \mathrm{meq} / \mathrm{L}\right)$. Samples of each plant were composited and sub-samples were taken from each composite and then dried in a forced air oven $\left(65^{\circ} \mathrm{C}\right)$ for $48 \mathrm{~h}$. Samples were ground using a Wiley mill (two-mm screen) and analyzed for total N (Kjeldahl method, Kjeltec 2300 Autoanalyzer, Foss Tecator AB, Hogans, Sweden), neutral detergent and acid detergent fiber (aNDF and ADF, respectively, Van Soest et al., 1991) and ash (AOAC, 2000, ID 942.05). Heat-stable $\alpha$-amylase was used in the aNDF assay (Udén et al., 2005). Non-protein $\mathrm{N}$ was chemically determined using trichloroacetic acid 78 (1 g/100 ml) solution (Licitra et al., 1996).

Eight dual-flow continuous culture fermenters (Hannah et al., 1986) were inoculated with ruminal fluid $(1,030 \mathrm{ml})$ from a Holstein cow. The cow was surgically fitted with a ruminal cannula made of soft plastic, housed in a wellventilated barn, had free access to water, and was fed a total mixed diet that was formulated to meet its nutrient requirements (NRC, 2001). The diet consisted of $1.8 \mathrm{~kg}$ alfalfa hay, $9.5 \mathrm{~kg}$ corn silage, $0.7 \mathrm{~kg}$ wheat straw, and 4.4 $\mathrm{kg}$ concentrate mix on a DM basis. The concentrate mix was composed of $31 \%$ ground corn, $20 \%$ dried molasses, $16.5 \%$ soybean meal, $20 \%$ soybean hull, $1.5 \%$ yeast, $2 \%$ blood meal, and 9\% vitamin-mineral mix. Ruminal fluid was collected using a vacuum pump approximately $2 \mathrm{~h}$ after the morning feeding (09:30), strained through four layers of cheese cloth, and anaerobically transported to the laboratory in a prewarmed insulated thermos.

The experimental period was $10 \mathrm{~d}$ in length, with seven $\mathrm{d}$ for adaptation followed by $3 \mathrm{~d}$ for sampling. Each fermenter was continuously infused with artificial saliva containing $0.5 \mathrm{~g}$ of urea/ $\mathrm{L}(\mathrm{pH}=8.25)$. Solid and liquid dilution rates were adjusted daily to approximate 0.05 and $0.10 \mathrm{~h}^{-1}$ respectively, by regulation of saliva input and filtrate removal rates. Temperature of fermenter contents was maintained at $38.6^{\circ} \mathrm{C} \pm 0.1$ by an electrical heater and the $\mathrm{pH}$ at $6.5 \pm 0.5$ by the addition of five $N \mathrm{HCl}$ or five $N$ $\mathrm{NaOH}$ through automated peristaltic pumps that were controlled by an electronic data acquisition system (Daisy $\mathrm{Lab}^{\circledR}$ ). Fermenters were constantly purged with $\mathrm{N}_{2}$ gas (40 $\mathrm{ml} / \mathrm{min}$ ) to preserve anaerobic condition. Fermenters were supplied daily with $75 \mathrm{~g}$ DM of pelleted Kochia scoparia or Atriplex dimorphostegia by an automated feeding mechanism adjusted to deliver the diet in eight equal portions over a 24-h period to establish steady-state conditions. Solid and liquid effluent weights were recorded daily at 09:00 and discarded until the last three days of the experiment. On the last 3 days, fermenter effluents were maintained at 2 to $4{ }^{\circ} \mathrm{C}$ by a cold water bath to retard microbial metabolism. Total effluent for each $24 \mathrm{~h}$ of the 3-d sample period was recorded, combined and homogenized (Power Gen Model 700) and a 1-L sample was removed by vacuum aspiration and stored at $-20^{\circ} \mathrm{C}$ for analysis. Fresh composite samples were used for total nitrogen $(\mathrm{N})$, ammonia-nitrogen $\left(\mathrm{NH}_{3}-\mathrm{N}\right)$ and volatile fatty acid (VFA) analyses. Freeze-dried samples were ground through a 1-mm screen and used for all other analyses (DM, OM, ash, aNDF, ADF, and purine). Bacterial samples (fluidassociated bacteria) were collected from fermenter contents on the last sampling day by straining the total content of each fermenter through two layers of cheese cloth. This strained fluid was centrifuged at $1,000 \mathrm{~g}$ for $10 \mathrm{~min}$ to remove feed particles and any protozoa that may have been present. The supernatant was centrifuged at $20,000 \mathrm{~g}$ for 20 min to isolate bacterial cells. The resulting supernatant fluid was discarded and the precipitate (bacterial cells) was re-suspended in de-ionized water for freeze drying. Bacterial cells were used to determine the concentration of purines that were used as a bacterial marker.

Total $\mathrm{N}$ of effluent samples was determined by macroKjeldal procedure (AOAC, 2000) and the bacterial $\mathrm{N}$ was determined using a true spec nitrogen analyzer (True Spec Series Leco, USA). Concentration of $\mathrm{NH}_{3}-\mathrm{N}$ in effluent samples was determined by direct stem distillation using a Kjeltec 2300 Autoanalyzer (Foss Tecator AB, Hogans, Sweden). Purine concentration in effluent and bacterial cells was determined using the method of Zinn and Owens (1986). Purine content of effluent and bacteria was used to partition flow of effluent $\mathrm{N}$ into bacterial and dietary nitrogen. Effluent VFA concentration was measured by gas chromatography (Hewlett-Packard, model 5880A, Palo Alto, CA) with a Carbopack DA/0.3\% Carbowax 20M column (Supelco, Bellefonte, PA).

Calculations and statistical analysis: Digestibility of nutrients was calculated using the following equations:

True digestibility

$=(($ total nutrient in DM of feed

-(total nutrient in DM of effluent

-total nutrient in bacterial mass))

/total nutrient in DM of feed

Bacterial $\mathrm{N}$ flow (g/d) was calculated directly from the 
total bacterial DM percentage obtained from the bacterial pellets isolated from culture contents and the mean flow rate of fermenter contents using the following equation:

Bacterial N flow (g/d)

= bacterial DM flow $(\mathrm{g} / \mathrm{d}) \times$ bacterial $\mathrm{N} \% / 100$

Efficiency of bacterial synthesis was calculated as follows:

Bacterial efficiency ( $\mathrm{g} \mathrm{N} / \mathrm{kg}$ of OM truly fermented)

$=($ bacterial $\mathrm{N}$ flow $(\mathrm{g} / \mathrm{d}) / \mathrm{OM}$ truly digested $(\mathrm{g} / \mathrm{d}))$ $\times 1,000$

Results were analyzed using the GLM procedure of SAS (1998) as a completely randomized design with fermenter flasks as replicates. Statistical differences between the two halophytic plants were determined using Duncan's multiple range test.

\section{RESULTS AND DISCUSSION}

\section{Chemical composition and digestion}

Some chemical composition of Kochia scoparia and Atriplex dimorphostegia is shown in Table 1. In agreement with Riasi et al. (2008) the DM, ash, aNDF and ADF content of Kochia was lower than Atriplex. However, there are some contradictions in chemical composition of halophytic forages between assays. In the present study CP content of Kochia was lower than some previous reports (Cohen et al., 1989; Madrid et al., 1996; Riasi et al., 2008). Differences among studies could be due to forage production condition, stage of harvesting, leaf:stem ratio or genetic variation (Gihad and El Shaer, 1992; Benjamin et al., 1995; El-Shatnawi and Abdullah, 2003). The NPN/CP ratio of Kochia and Atriplex (0.032 and 0.053, respectively) was

Table 1. Chemical composition (g/kg of DM) of Kochia scoparia and Atriplex dimorphostegia

\begin{tabular}{|c|c|c|}
\hline \multirow{2}{*}{ Chemical composition ${ }^{1}$} & \multicolumn{2}{|c|}{ Forages } \\
\hline & Kochia & Atriplex \\
\hline$\overline{\mathrm{DM}}$ & 321.0 & 380.0 \\
\hline $\mathrm{OM}$ & 898.0 & 854.0 \\
\hline $\mathrm{CP}$ & 74.1 & 85.3 \\
\hline Ash & 102.0 & 146.0 \\
\hline Fat & 14.0 & 11.0 \\
\hline NFC & 376.0 & 221.0 \\
\hline NPN/CP & 0.032 & 0.053 \\
\hline aNDF & 434.0 & 537.0 \\
\hline $\mathrm{ADF}$ & 297.0 & 435.0 \\
\hline
\end{tabular}

${ }^{1} \mathrm{DM}=$ Dry matter; $\mathrm{CP}=$ Crude protein; $\mathrm{OM}=$ Organic matter; $\mathrm{NFC}=$ Nonfibrous carbohydrates, NPN $=$ Non-protein $\mathrm{N} ;$ aNDF $=$ Neutral detergent fiber; $\mathrm{ADF}=\mathrm{Acid}$ detergent fiber. relatively lower than the common forages such as alfalfa hay. This finding is important, because NPN content can influence CP quality of forages for ruminants (Cohen et al., 1989; Ben Salem et al., 2004).

Nutrient digestibility of Kochia scoparia and Atriplex dimorphostegia is shown in Table 2. There was no difference $(p>0.05)$ between true DM digestibility of Kochia compared with Atriplex. In general, DM digestibility determined using in vitro methods is lower than digestibility determined using in vivo and in situ methods (Stern et al., 1997). Consistent with this observation, true DM digestibility of Kochia (397 g/ kg) and Atriplex (426 $\mathrm{g} / \mathrm{kg}$ ) (Table 2) was lower than DM digestibility of Kochia and Atriplex determined using an in situ procedure (444 and $472 \mathrm{~g} / \mathrm{kg}$, respectively) (Riasi et al., 2008).

Although the OM content of Kochia was higher than Atriplex (898 vs. 854 g/kg) (Table 1), Atriplex had higher true OM digestibility compared with Kochia. Ghadaki et al. (1975) determined nutritive values of introduced and native range plants grown under natural conditions in Iran and showed that the shrubs had higher percentages of lignin, and there was a relationship between their lignin content and in vitro true OM digestibility. However, it should be noted that moisture, pressure, and heat applied to continuous culture diets during pelleting may reduce the OM digestibility (Stern et al., 1997).

Kochia and Atriplex had about 50\% true CP digestibility and there was no difference $(p>0.05)$ between the two Halophytes. The CP digestibility of Kochia and Atriplex (Table 2) was higher than values reported by Danesh Mesgaran and Stern (2005). However, concordant with Danesh Mesgaran et al. (2004) and Riasi et al. (2008), there were no differences $(p>0.05)$ between CP digestibilities of the two halophytic plants.

The aNDF digestibility of Atriplex was higher $(\mathrm{p}<0.05)$ than that of Kochia while ADF digestibility showed the opposite effect $(p<0.05)$. These results may be related to chemical composition of plants regarding variations in attachments of hemicellulose to phenolic rings (Moore and

Table 2. Nutrient digestibility of Kochia scoparia and Atriplex dimorphostegia ( $\mathrm{g} / \mathrm{kg}$ of nutrient) in continuous culture fermenters ${ }^{1}$

\begin{tabular}{lccc}
\hline \multirow{2}{*}{ Digestibility } & \multicolumn{2}{c}{ Halophyte forages } & \multirow{2}{*}{ SEM $^{2}$} \\
\cline { 2 - 3 } & Kochia & Atriplex & \\
\hline True $\mathrm{DM}^{3}$ & 397 & 426 & 11.1 \\
True OM $^{3}$ & $398^{\mathrm{b}}$ & $450^{\mathrm{a}}$ & 12.1 \\
True CP & 565 & 585 & 25.2 \\
NDF & $348^{\mathrm{b}}$ & $411^{\mathrm{a}}$ & 16.0 \\
ADF & $406^{\mathrm{a}}$ & $232^{\mathrm{b}}$ & 30.9 \\
\hline
\end{tabular}

${ }^{1}$ Each value is the mean of four fermenters.

${ }^{2}$ Standard error of the mean. ${ }^{3}$ Corrected for bacterial contribution.

${ }^{a, b}$ Mean in the same row with different superscripts differ $(\mathrm{p}<0.05)$ 
Cherney, 1986) and/or a limitation in availability of certain nutrients such as valerate, branched-chain VFA and amino acids that are required by cellulolytic bacteria (Hoover, 1986; Hussein et al., 1991). In agreement with Mansfield et al. (1994) who observed a negative relationship between NFC concentration of diets and NDF digestibility values, our study showed that NFC concentrations of Kochia and Atriplex (376 and $221 \mathrm{~g} / \mathrm{kg}$, respectively) (Table 1) may have affected their NDF digestibility. A lower concentration of valerate with Atriplex (Table 3) might have affected its ADF digestibility (Table 2) (Hoover, 1986).

Volatile fatty acids: Total daily VFA concentration $(\mathrm{mol} / \mathrm{d})$ and molar proportions of the major VFA (acetate, propionate, butyrate, and valerate) are presented in Table 3. Total VFA concentration of Atriplex was higher $(\mathrm{p}<0.05)$ than that Kochia $(0.037$ vs. $0.026 \mathrm{~mol} / \mathrm{d})$. Mansfield et al. (1994) noted that in continuous culture fermenters, total VFA production decreased as RDP concentration in the diets decreased. In the current experiment, the two halophytic plants had similar CP digestion, so the higher total VFA concentration of Atriplex may be attributed to true OM digestibility (Table 2).

There were no differences $(p>0.05)$ between the two halophytic plants in molar proportions of acetate and propionate. According to Mansfield at al. (1994) who showed that molar proportions of butyrate decreased and acetate increased as dietary NFC concentration decreased, molar proportion of butyrate was $(\mathrm{p}<0.05)$ lower with Atriplex $(\mathrm{NFC}=221 \mathrm{~g} / \mathrm{kg}$ ) compared with Kochia (NFC = $376 \mathrm{~g} / \mathrm{kg}$ ). Mansfield at al. (1994) reported a switch from NFC to fiber fermentation when dietary NFC was reduced. The major source of variation affecting molar proportions of ruminal VFA is OM digestibility, so that feeding more digestible forages is associated with lower proportions of acetate and higher proportions of both propionate and butyrate (Lopez et al., 2000). However, our data showed in addition to higher OM digestibility of Atriplex its butyrate

Table 3. Volatile fatty acid concentration and molar proportions of individual volatile fatty acids of Kochia scoparia and Atriplex dimorphostegia in continuous culture fermenters ${ }^{1}$

\begin{tabular}{lccl}
\hline \multirow{2}{*}{ Item } & \multicolumn{2}{c}{ Halophyte forages } & \multirow{2}{*}{ SEM $^{2}$} \\
\cline { 2 - 3 } & Kochia & Atriplex & \\
\hline Total VFA (mol/d) & $0.026^{\mathrm{b}}$ & $0.037^{\mathrm{a}}$ & 0.003 \\
Individual VFA (mol/100 mol) & & & \\
$\quad$ Acetate & 72.0 & 75.2 & 2.0 \\
Propionate & 18.1 & 20.0 & 1.5 \\
Butyrate & $8.4^{\mathrm{a}}$ & $4.2^{\mathrm{b}}$ & 0.6 \\
$\quad$ Valerate & $0.9^{\mathrm{a}}$ & $0.5^{\mathrm{b}}$ & 0.01 \\
Branched chain VFA & 0.01 & 0.02 & 0.005 \\
\hline${ }^{1}$ Each value is the mean of four fermenters. & & \\
${ }^{2}$ Standard error of the mean. & & \\
${ }^{\mathrm{a}, \mathrm{b}}$ Mean in the same row with different superscripts $(\mathrm{p}<0.05)$. &
\end{tabular}

was lower than that Kochia. This finding may be attributed to factors that induce changes in various parameters of the rumen environment (osmotic pressure, redox potential, $\mathrm{pH}$, and turnover rate). In the present study concentrations of valerate of Kochia $(0.9 \mathrm{~mol} / 100 \mathrm{~mol})$ was higher $(\mathrm{p}<0.05)$ than that of Atriplex $(0.5 \mathrm{~mol} / 100 \mathrm{~mol})$ and the concentration of branched chain VFA (BCVFA) was too low. Consistent with our data, other research indicated that decreasing dietary NFC (Mansfield et al., 1994) reduced concentration of either valerate and one or more of the branched-chain VFA.

Nitrogen metabolism: Nitrogen intake, $\mathrm{NH}_{3}-\mathrm{N}, \mathrm{N}$ flow, and bacterial protein synthesis are presented in Table 4. No difference $(p>0.05)$ was observed between Kochia and Atriplex in regard to $\mathrm{NH}_{3}-\mathrm{N}$ concentrations, total $\mathrm{N}$ flow, $\mathrm{NH}_{3}-\mathrm{N}$ flow, non $\mathrm{NH}_{3}-\mathrm{N}$ flow, bacterial $\mathrm{N}$ flow, and dietary $\mathrm{N}$ flow; however, efficiency of bacterial protein synthesis was higher $(\mathrm{p}<0.05)$ for Kochia compared with Atriplex (5.96 vs. $4.85 \mathrm{~g}$ of $\mathrm{N} / \mathrm{kg}$ of OM truly digested).

A concentration of $5 \mathrm{mg} / \mathrm{dl}$ of $\mathrm{NH}_{3}-\mathrm{N}$ has been suggested as the minimum amount required to maximize efficiency of bacterial growth (Satter and Slyter, 1974). This value is lower than that obtained for Kochia and Atriplex (8.57 and $9.73 \mathrm{mg} / \mathrm{dl}$, respectively) in the present study. Ariza et al. (2001) reported that $\mathrm{NH}_{3}-\mathrm{N}$ concentration in the fermenters depends on the extent of $\mathrm{CP}$ degradation and $\mathrm{N}$ uptake by ruminal bacteria. Fractions of $\mathrm{N}$ flow were not different $(p>0.05)$ between the two halophytic forages which is probably due to the small difference between $\mathrm{N}$ intakes. In general, total $\mathrm{N}$ flow and its fractions for halophytic plants were lower than those previous reported for different diets using the continuous culture procedure (Hussein et al., 1991; Mansfield et al., 1994).

The lower efficiency of bacterial protein synthesis obtained with Atriplex was not a result of limited $\mathrm{NH}_{3}-\mathrm{N}$,

Table 4. Nitrogen metabolism of Kochia scoparia and Atriplex dimorphostegia in continuous culture fermenters ${ }^{1}$

\begin{tabular}{|c|c|c|c|}
\hline \multirow{2}{*}{ Item } & \multicolumn{2}{|c|}{ Halophyte forages } & \multirow{2}{*}{$\mathrm{SEM}^{2}$} \\
\hline & Kochia & Atriplex & \\
\hline $\mathrm{N}$ intake $(\mathrm{g} / \mathrm{d})$ & 1.23 & 1.27 & 0.04 \\
\hline Ammonia N (mg/dl) & 8.57 & 9.73 & 0.87 \\
\hline \multicolumn{4}{|l|}{$\mathrm{N}$ flow $(\mathrm{g} / \mathrm{d})$} \\
\hline Total N & 0.67 & 0.68 & 0.02 \\
\hline Ammonia N & 0.13 & 0.14 & 0.02 \\
\hline Non-ammonia $\mathrm{N}$ & 0.53 & 0.53 & 0.01 \\
\hline Bacterial N & 0.16 & 0.14 & 0.03 \\
\hline Dietary N & 0.37 & 0.39 & 0.02 \\
\hline \multicolumn{4}{|l|}{ Bacterial protein synthesis } \\
\hline $\mathrm{g}$ of $\mathrm{N} / \mathrm{kg}$ of OM truly digested & $5.96^{\mathrm{a}}$ & $4.85^{\mathrm{b}}$ & 0.04 \\
\hline
\end{tabular}


because its concentrations were about two fold that recommended by Satter and Slyter (1974) for maximum microbial growth to be achieved. Hence, other factors such as availability of small peptides and (or) certain amino acids may have been limiting when Atriplex was fed to the fermenters. It has been shown that an inverse relationship can exist between VFA and microbial biomass production (William, 2000). Consistent with this observation, when Atriplex was fed to the fermenters, total VFA yield (mol/d) was higher (Table 3) and efficiency of bacterial protein synthesis was lower (Table 4) than that of Kochia. It has been suggested that the type of carbohydrate and its rate of fermentation could influence efficiency when expressed as total synthesis of microbial protein per unit of gas produced (William, 2000).

\section{IMPLICATIONS}

Kochia scoparia and Atriplex dimorphostegia had similar digestibility of DM and CP, while the apparent and true OM, NDF and ADF digestibilities of these halophytic plants differed. Considering that VFA concentration of Kochia scoparia and Atriplex dimorphostegia was relatively low, it appears that these halophytic plants may not have enough digestible energy for high producing ruminants. It seems that lower dietary NFC in Atriplex compared with Kochia reduced its concentration of valerate. Degradability of CP from Kochia scoparia and Atriplex dimorphostegia seemed to achieve a concentration of $\mathrm{NH}_{3}-\mathrm{N}$ that maximized bacterial growth $(>5 \mathrm{mg} / \mathrm{dl})$, however efficiency of bacterial protein synthesis differed between the two halophytic plants and the reason for this observation is unclear.

\section{ACKNOWLEDGEMENTS}

This work was conducted with the financial support of the University of Minnesota, St. Paul, USA and Ferdowsi University of Mashad, Iran.

\section{REFERENCES}

Ariza, P., A. Bach, M. D. Stern and M. B. Hall. 2001. Effects of carbohydrates from citrus pulp and hominy feed on microbial fermentation in continuous culture. J. Anim. Sci. 79:2713-2718.

AOAC. 2000. Official methods of analysis. 15th edn. Official Methods of Analysis of AOAC International, Arlington, Virginia, USA.

Benjamin, R. W., Y. Lavie, M. Forti, D. Barkai, R. Yonatan and Y. Hefetz. 1995. Annual regrowth and edible biomass of two species of Atriplex and Cassia sturtii after browsing. J. Arid Environ. 29: 63-84.

Ben Salem, H., A. Nefzaoui and L. Ben Salem. 2004. Spineless cactus (Opuntia ficus-indica $f$. inermis) and oldman saltbush
(Atriplex nummularia L.) as alternative supplements for growing Barbarine lambs given straw-based diets. Small Rumin. Res. 51:65-73.

Cohen, R. D. H., A. D. Iwaasa, M. E. Mann, E. Coxworth and J. A. Kernan. 1989. Studies on the feeding value of Kochia scoparia (L.) Schrad. Hay for beef cattle. Can. J. Anim. Sci. 69:735-743.

Danesh Mesgaran, M., A. Riasi and M. D. Stern. 2004. Chemical composition and in vitro and in situ protein digestibility of some halophytes located in central Iran. In: Proceeding of the 2004 British Society of Animal Science, p. 242.

Danesh Mesgaran, M. and M. D. Stern. 2005. Ruminal and postruminal protein disappearance of various feeds originating from Iranian plats varieties determined by the in situ mobile bag technique and alternative methods. Anim. Feed Sci. Technol. 118:31-46.

El- Shatnawi, M. K. J. and M. Turuk. 2002. Dry matter accumulation and chemical content of saltbush (Atriplex halimus) grown in Mediterranean desert shurblands. New Zealand J. Agric. Res. 45:139-144.

El-Shatnawi, M. K. J. and A. Y. Abdullah. 2003. Composition changes of Atriplex nummularia L. under Mediterranean arid environment. Afr. J. Range Forage Sci. 20:253-257.

Ghadaki, M. B., P. J. Van Soest, R. E. McDowell and B. Malekpour. 1975. Chemical composition and in vitro digestibility of some range forage species of Iran. In: Proceeding of the 1975 Evaluation and Mapping of Tropical African Rangelands Seminar.

Gihad, E. A. and H. M. El Shaer. 1992. Utilization of halophytes by livestock on rangelands. In: Halophytes as a Source of Livestock and for Rehabilitation of Degraded Lands Squires (Ed. V. R. Ayoub). Kluwer Academic Publishers, Dordrecht. pp. 77-96.

Hannah, S. M., M. D. Stern and F. R. Ehle. 1986. Evaluation of dual flow continuous culture system for estimating bacterial fermentation in vivo of mixed diets containing various soybean products. Anim. Feed Sci. Technol. 16:51-62.

Hoover, W. H. 1986. Chemical factors involved in ruminal fiber digestion. J. Dairy Sci. 69:2755-2766.

Hussein, H. S., M. D. Stern and R. M. Jordan. 1991. Influence of dietary protein and carbohydrate sources on nitrogen metabolism and carbohydrate fermentation by ruminal microbes in continuous culture. J. Anim. Sci. 69:2123-2133.

Licitra, G., T. M. Hernandez and P. J. Van Soest. 1996. Standardization of procedures for nitrogen fractionation of ruminant feeds. Anim. Feed Sci. Technol. 57:347-358.

Lopez, S., J. Dijkstra and J. France. 2000. Prediction of energy supply in ruminants, with emphasis on forages. In: Forage Evaluation in Ruminant Nutrition (Ed. D. I. Given, E. Owen, R. F. E. Axford and H. M. Omed) CABI Publishing. Oxon, UK. pp. 63-94.

Madrid, J., F. Hernandez, M. A. Oulgar and J. M. Cid. 1996. Nutritive value of Kochia scoparia L. and ammoniated barley straw for goats. Small Rumin. Res. 19:213-218.

Mansfield, H. R., M. I. Endres and M. D. Stern. 1994. Influence of non-fibrous carbohydrate and degradable intake protein on fermentation by ruminal microorganisms in continuous culture. J. Anim. Sci. 72:2464-2474.

Michalet-Doreau, B. and M. Y. Ould-Bah. 1992. In vitro and in sacco methods for the estimation of dietary nitrogen 
degradability in the rumen: a review. Anim. Feed Sci. Technol. 40:57-86.

Moore, K. J. and J. H. Cherney. 1986. Digestion kinetics of sequentially extracted cell component of forages. Crop Sci. 26: 1230-1235.

National Research Council. 2001. Nutrient requirements of dairy cattle. Seventh Revised Edition. Natl. Acad. Sci., Washington, DC, USA.

Riasi, A. and M. Danesh Mesgaran. 2008. Chemical composition and digestible parameters of various halophytes, In: Crop and Forage Production Using Saline Waters (Ed. M. Kafi and M. Ajmal Khan). NAM S and T CENTER, Dehli, India. pp. 97106.

Riasi, A., M. Danesh Mesgaran, M. D. Stern and M. J. Ruiz Moreno. 2008. Chemical composition, in situ ruminal degradability and post-ruminal disappearance of dry matter and crude protein from the halophytic plants Kochia scoparia, Atriplex dimorphostegia, Suaeda arcuata and Gamanthus gamacarpus. Anim. Feed Sci. Technol. 141:209-219.

Satter, L. D. and L. L. Slyter. 1974. Effect of ammonia concentration on rumen microbial protein production in vitro. $\mathrm{J}$. Nut. 32:199-208.
SAS Institute Inc. 1989. SAS/STAT user's guide: Version 6. 4th edn. SAS Institute Inc., Cary, North Carolina.

Stern, M. D., A. Bach and S. Calsamiglia. 1997. Alternative techniques for measuring digestion in ruminants. J. Anim. Sci. 75:2256-2276.

Uden, P., P. H. Robinson and J. Wiseman. 2005. Use of detergent system terminology and criteria for submission of manuscripts on new or revised, analytical methods as well as descriptive information on feed analysis and/or variability. Anim. Feed Sci. Technol. 118:181-186.

Van Soest, P. J., J. B. Roberson and B. A. Lewis. 1991. Methods for dietary fiber, neutral detergent fiber, and nonstarch polysaccharides in relation to animal nutrition. J. Dairy Sci. 74:3583-3597.

Williams, B. A. 2000. Cumulative gas-production techniques for forage evaluation. In: Forage Evaluation in Ruminant Nutrition (Ed. D. I. Given, E. Owen, R. F. E. Axford and H. M. Omed) CABI Publishing. Oxon, UK. pp. 189-213.

Zinn, R. A. and F. N. Owens. 1986. A rapid procedure for purine measurement and its use for estimating net ruminal protein synthesis. Can. J. Anim. Sci. 66:157-166. 